\title{
Mosquito (Diptera: Culicidae) fauna in parks in greater São Paulo, Brazil
}

\author{
Marcia Bicudo de Paula ${ }^{1}$, Aristides Fernandes ${ }^{1}$, Antônio Ralph Medeiros-Sousa ${ }^{1}$, Walter Ceretti-Júnior ${ }^{1}$, \\ Rafael Christe ${ }^{I}$, Regina Claudia Stroebel', Leila Pedrosa ${ }^{2}$, Rosa Maria Marques de Sá Almeida ${ }^{\text {, }}$ \\ Gabriela Cristina de Carvalho ${ }^{1}$, Uellinton Damasceno Pereira ${ }^{3}$, Marcelo Cassiano de Oliveira Jacintho ${ }^{3}$ \\ Delsio Natal ${ }^{1}$ \& Mauro Toledo Marrelli, ${ }^{1,4}$ \\ ${ }^{1}$ Universidade de São Paulo, Faculdade de Saúde Pública, Departamento de Epidemiologia, São Paulo, \\ SP, Brasil. \\ ${ }^{2}$ Prefeitura do Município de São Paulo, Secretaria do Verde e Meio Ambiente, Departamento de Parques \\ e Áreas Verdes, São Paulo, SP, Brasil. \\ ${ }^{3}$ Prefeitura do Município de São Paulo, Secretaria Municipal da Saúde, Coordenação de Vigilância em \\ Saúde, Centro de Controle de Zoonoses, Laboratório de Identificação e Pesquisa em Fauna Sinantrópica, \\ São Paulo, SP, Brasil. \\ ${ }^{4}$ Corresponding author: Mauro Marrelli, e-mail: mtmarrelli@gmail.com
}

PAULA, M.B., FERNANDES, A., MEDEIROS-SOUSA, A.R., CERETTI-JUNIOR, W., CHRISTE, R.O., STROEBEL, R., PEDROSA, L., ALMEIDA, R., CARVALHO, G.C., PEREIRA, U., JACINTHO, M., NATAL, D., MARRELli, M.T. Mosquito (Diptera: Culicidae) fauna in parks in greater São Paulo, Brazil. Biota Neotropica. 15(3): e20140026. http://dx.doi.org/10.1590/1676-0611-BN-2014-0026

\begin{abstract}
Municipal parks in the city of São Paulo, which are used for leisure purposes, contain remnants of the flora of the Atlantic Forest, as well as lakes and springs, and are home to mammals, birds and arthropods, some of which can be vectors of disease. The eastern side of the city has the largest population in São Paulo and twenty-four municipal parks. The aim of this study was to investigate Culicidae fauna in two parks on this side of the city and to determine which of the Culicidae species identified have the potential to act as bioindicators and vectors of human pathogens. Culicidae were collected monthly between March 2011 and February 2012 in Carmo Park and Chico Mendes Park with battery-powered aspirators, Shannon traps and CDC traps for adult mosquitoes, and larval dippers and suction samplers for immature mosquitoes. To confirm sample sufficiency, the EstimateS program was used to plot sample-based species accumulation curves and estimate total richness by the Jackknife 1 method. In all, 1,092 culicids from nine genera (Aedes, Anopheles, Coquillettidia, Culex, Limatus, Mansonia, Trichoprosopon, Toxorhynchites and Uranotaenia) and nineteen taxonomic units were collected in Carmo Park. Coquillettidia venezuelensis (Theobald 1912), Aedes scapularis (Rondani 1848) and Culex (Culex) spp. Linnaeus 1758 were the most abundant adults, and Culex (Melanoconion) spp. Theobald 1903 and Anopheles strodei Root 1926 the most abundant immature mosquitoes. In Chico Mendes Park 4,487 mosquitoes in six genera and eighteen taxonomic units were collected. Culex (Cux.) spp. and Ae. scapularis were the most abundant adults, and Ae. albopictus (Skuse 1984) the most abundant immature mosquitoes. The species accumulation curves in both parks were close to the asymptote, and the total richness estimate was close to the observed richness. Some culicid taxons are bioindicators of environmental conditions in the areas they inhabit. It is important to monitor native fauna in municipal parks in São Paulo as various species in this study were found to have vector competence and capacity to transmit pathogens, such as arboviruses.
\end{abstract}

Keywords: Diversity, culicids, mosquitoes, municipal parks.

PAULA, M.B., FERNANDES, A., MEDEIROS-SOUSA, A.R., CERETTI-JUNIOR, W., CHRISTE, R.O., STROEBEL, R., PEDROSA, L., ALMEIDA, R., CARVAlHO, G.C., PEREIRA, U., JACINTHO, M., NATAL, D., MARRELLI, M.T. Fauna de mosquitos (Diptera: Culicidae) em parques da cidade de São Paulo, Brasil. Biota Neotropica. 15(3): e20140026. http://dx.doi.org/10.1590/1676-0611-BN-2014-0026

Resumo: Em São Paulo os parques municipais preservam resquícios da vegetação de Mata Atlântica, comportam lagos e nascentes, servem de abrigos para mamíferos, aves e artrópodes vetores. São frequentados pela população humana como ambientes de lazer. A zona Leste da cidade possui o maior índice populacional de habitantes e 24 parques municipais. O objetivo deste trabalho foi conhecer a fauna de Culicidae de dois parques da zona Leste da cidade e avaliar a presença de espécies potencialmente bioindicadoras e vetoras de patógenos ao homem. Foram feitas coletas mensais de 
culicídeos entre março de 2011 a fevereiro de 2012 no Parque do Carmo e no Parque Chico Mendes, com aspiradores elétricos, armadilhas de Shannon e CDC para mosquitos adultos e concha entomológica e bombas manuais de sucção para os imaturos. Para verificar a suficiência amostral foram construídas curvas de acúmulo de espécies por amostragem e a riqueza total foi estimada pelo método Jackknife 1, ambos gerados pelo programa EstimateS. No parque do Carmo foram coletados 1.092 culicídeos, distribuídos em nove gêneros (Aedes, Anopheles, Coquillettidia, Culex, Limatus, Mansonia, Trichoprosopon, Toxorhynchites e Uranotaenia), distribuídos em 19 unidades taxonômicas. Coquillettidia venezuelensis(Theobald 1912), Aedes scapularis (Rondani 1848)e Culex (Culex) spp. Linnaeus 1758 foram os adultos mais abundantes e Culex (Melanoconion) spp. Theobald 1903 e Anopheles strodei Root 1926 os imaturos. No Parque Chico Mendes obteve-se 4.487 mosquitos, distribuídos em seis gêneros e 18 unidades taxonômicas. Culex (Cux.) spp. e Ae. scapularis foram os mais abundantes dos adultos e Ae. albopictus (Skuse 1984) dos imaturos. As curvas de acúmulo de espécies por amostragem em ambos os parques chegaram próximas à assíntota e a estimativa de riqueza total mostrou-se próxima à riqueza observada. Alguns táxons de culicídeos são bioindicadores das condições ambientais dos locais onde vivem, portanto é necessário acompanhar a fauna nativa dos parques municipais porque várias espécies encontradas têm mostrado competência e capacidade para veicular patógenos e arbovírus.

Palavras-chave: Diversidade, mosquitos, culicídeos, Parques municipais.

\section{Introduction}

The city of São Paulo, in the state of São Paulo in the southeast of Brazil, has a population of over 11 million people and is considered the region with the highest population density in South America. If all the adjacent municipalities, which together with the metropolis form an extensive built-up area, are included, the population is around 20.8 million, making it one of the largest megalopolises in the world. The eastern side of the city has the highest population approximately 3.8 million inhabitants (IBGE 2010).

For a long time the authorities have paid little attention to this area of the city as it was one that saw the proliferation of lowincome districts as a result of the disorganized occupation of land (shanty towns) on the outskirts of the city. In recent decades, with urban growth and the increasing expansion of business and commercial centers, the region has become a focus for property development, with the construction of countless business developments and middle-class residential condominiums. More recently, the construction of a large soccer stadium, together with investments in road infrastructure, has transformed this region into a magnet for shops. In addition, the expansion of the subway, investments in new educational and university centers and the growth in the economy are just some of the factors that have completely transformed this part of the city.

All of these factors, together with the demographic pressure exerted by the east side of São Paulo, have contributed to the increase in population density in the neighboring municipality of Guarulhos, making it the second largest built-up area in the state of São Paulo. São Paulo International Airport, which is also known as Governador André Franco Monteiro Airport, is the largest in South America and is located in Guarulhos; around 100,000 employees, passengers and visitors pass through the airport every day (EMPLASA 2011).

Municipal parks in the city of São Paulo contain remnants of the flora of the Atlantic Forest, as well as lakes and springs, and are home to mammals, birds and arthropods, some of which can be vectors of disease. The parks are in continual use for leisure purposes (Medeiros-Sousa et al. 2013). Twenty-four of the more than 100 parks in the city (Moreti \& Fungaro 2012) are to be found on the east side, notable among these being Carmo Park and Chico Mendes Park, which are the subject of this study.
Around 3,500 species of Culicidae have been described around the world, some of which are of importance in public health because they are vectors of human and animal pathogens (Stone et al. 1959, Belkin et al. 1966, Harbach 2013). Various culicid species can be found in the habitats in these urban parks, where their populations are protected and can be maintained (Medeiros-Sousa et al. 2013). The proximity of these hematophagous insects to the human population allows contact between humans and mosquitoes, increasing the risk of the emergence of infectious diseases, particularly those caused by arboviruses. In light of this emerging epidemiological picture, it is important to identify mosquito species in these locations and to determine their potential as vectors. Furthermore, carrying out an entomological investigation into the species composition of Culicidae mosquitoes in urban parks helps to underline the importance of keeping these areas in anthropic environments by showing the biological richness of these enclaves. A knowledge of the culicid population in these environments helps to identify bioindicator species that can be useful when assessing the quality of the environment (Montes 2005; Anjos \& Navarro-Silva 2008). The aim of this study was therefore to investigate Culicidae fauna in two parks on the east side of São Paulo and to determine which of the Culicidae species identified have the potential to act as bioindicators and vectors of human pathogens.

\section{Materials and Methods}

\section{Collection Areas and Methods}

The areas used for collections in this study consisted of forest fragments and the surrounding areas inside two municipal parks in the east of the city of São Paulo. These two environments are described in more detail below.

Carmo Park (2333'59' S, 46 $28^{\circ} 04^{\prime}$ ' W) and Chico Mendes Park (2330'24" S, $46^{\circ} 25^{\prime} 45^{\prime}$ ' W), the areas chosen for the study are notable for the large number of visitors they receive every month and for their size (Figure 1).

Carmo Park (Olavo Egydio Setúbal Park) was inaugurated on September 19th, 1976, and is considered the second largest municipal park in the city. It has an area of 2,388,930 $\mathrm{m}^{2}$ with various lakes and is home to mammals, amphibious animals, reptiles and wild and domesticated birds. An area of $839,300 \mathrm{~m}^{2}$ 


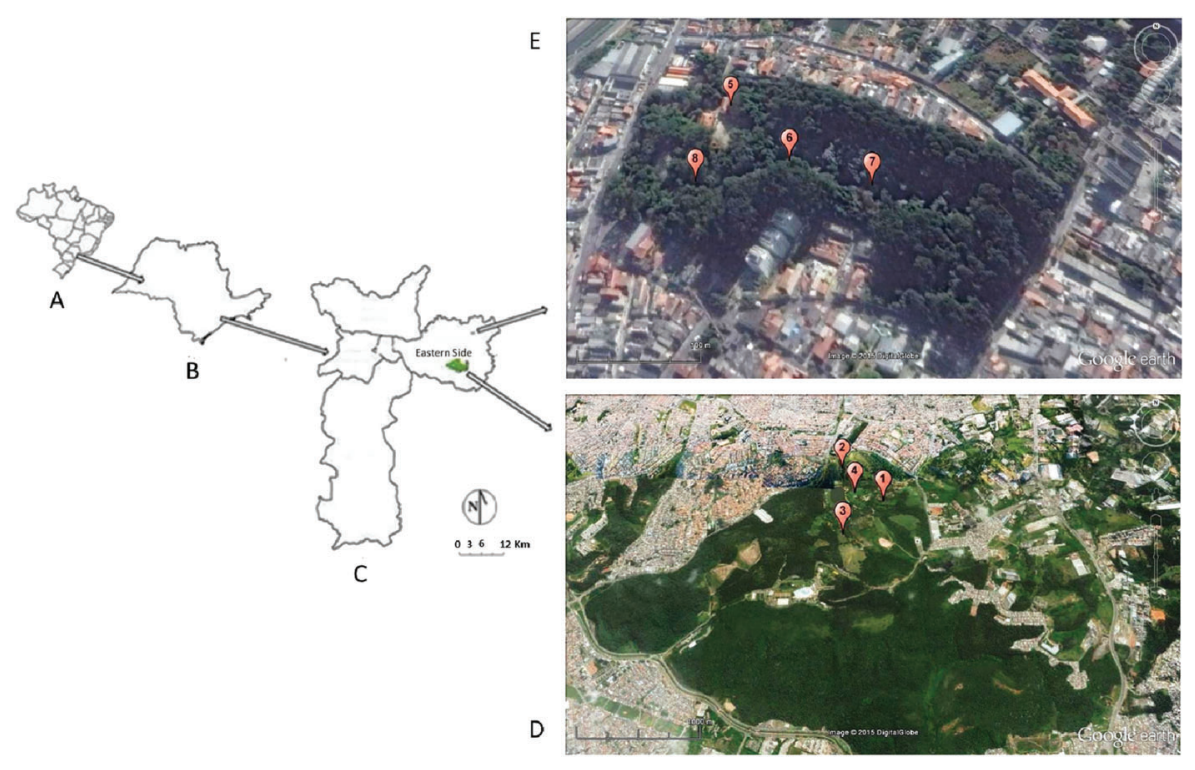

Figure 1. Location of Carmo Park (D) and Chico Mendes Park (E) in the east side of the municipality of São Paulo (C) in the state of São Paulo (B) in Brazil (A). Geographic coordinates of each collection point of Carmo Park: 1- Wooded area close to the administration buildings

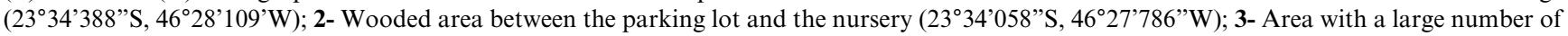

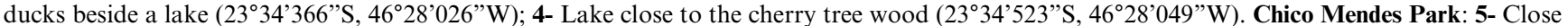
to the administration buildings $\left(23^{\circ} 30^{\prime} 353^{\prime}\right.$ 'S, $\left.46^{\circ} 25^{\prime} 681^{\prime \prime} \mathrm{W}\right)$; 6- Trail leading to the lake $\left(23^{\circ} 30^{\prime} 410^{\prime \prime} \mathrm{S}, 46^{\circ} 25^{\prime} 599^{\prime \prime} \mathrm{W}\right)$; 7- Trail used by walkers $\left(23^{\circ} 30^{\prime} 375^{\prime}\right.$ 'S $\left.46^{\circ} 25^{\prime} 590^{\prime \prime} \mathrm{W}\right)$; 8- Wood along the edge of the lake $\left(23^{\circ} 30^{\prime} 430^{\prime \prime} \mathrm{S}, 46^{\circ} 25^{\prime} 681^{\prime \prime} \mathrm{W}\right)$.

where the São Mateus sanitary landfill used to operate was recently added to the park. The flora consists mainly of remnants of the Atlantic Forest with riparian forest, anthropic vegetation, marshes, lawns, eucalyptus groves, an orchard, a coffee grove, an Okinawa cherry tree wood and a nursery for different species of bushes. In the surrounding area there are houses occupied by low-income families. Between 5,000 and 50,000 people visit the park every month.

Chico Mendes Ecological Park was inaugurated on June 4 th, 1989. It extends over an area of $61,600 \mathrm{~m}^{2}$ and has streams, lakes and springs. The fauna consists mainly of mammals and wild and domesticated birds. The flora is made up of remnants of the Atlantic Forest, a eucalyptus grove, an orchard and areas that have been turned into gardens. The area surrounding the park consists of houses occupied by low-income families. Around 22,500 people visit the park every month.

Field visits were made monthly between March 2011 and February 2012, totalizing twelve samplings in each park. Specimens were collected using four different techniques as follows: (i) Shannon traps, from which specimens were collected for two hours starting at evening twilight by two individuals wearing personal protective equipment; (ii) CDC light traps with $200 \mathrm{~g}$ of dry ice placed $1 \mathrm{~m}$ above the ground (two traps) and in the canopy $5 \mathrm{~m}$ above the ground (two traps) for three hours; (iii) three $12 \mathrm{~V}$ battery-powered aspirators used in a standardized 20 minute collection effort (Nasci 1981); and (iv) an active search for immature specimens in breeding sites with a $400 \mathrm{~mL}$ larval dipper or suction samplers depending on where the collection was being carried out. Throughout the study period it was performed about 240 hours of sampling effort in each park, divided as follows: 12 hours of aspiration, 24 hours of Shannon trap, 144 hours of CDC traps and 60 hours of active search for immature forms.

In Carmo Park the collections were performed in the following areas: 1- a wooded area close to the administration buildings; 2- a wooded area between the parking lot and the nursery; 3- an area with a large number of ducks beside a lake; and 4- a lake close to the cherry tree wood. In Chico Mendes Park the areas selected were: 5- close to the administration buildings; 6- on a trail leading to the lake; 7- on a trail used by walkers; and 8- in a wood along the edge of the lake (Figure 1).

\section{Species identification}

After they had been collected, the adult culicids were sacrificed using chloroform and stored in plastic pots, labeled and prepared for dehydration with silica gel. Immature specimens were transported in labeled $200 \mathrm{~mL}$ plastic pots containing water from the breeding site and kept in a styrofoam box. All the material collected was transported to the Laboratory for Research into and Identification of Synanthropic Fauna at the Zoonosis Control Center, in the city of São Paulo, then to the Entomology Laboratory at the Faculty of Public Health, University of São Paulo, where the specimens were identified. Immature individuals were kept until they reached the adult stage. Morphological identification was based on Lane (1953), Consoli \& Lourenço-de-Oliveira (1994) and Forattini (2002), as well as on comparison with standard specimens in the collection at the Faculty of Public Health, University of São Paulo. The abbreviations for genera and subgenera used here follow the standardization proposed by Reinert (2001).

To confirm sample sufficiency, the EstimateS program was used to plot sample-based species accumulation curves and estimate total richness by the Jackknife 1 method (Burnham \& Overton 1979); 1000 randomizations without replacement and a $95 \%$ confidence interval were used (Colwell et al., 2004).

\section{Results}

In all, 5,579 specimens of Culicidae were captured (Tables 1 and 2). Collections in Carmo Park yielded 837 adult mosquitoes 
Paula, M.B. et al.

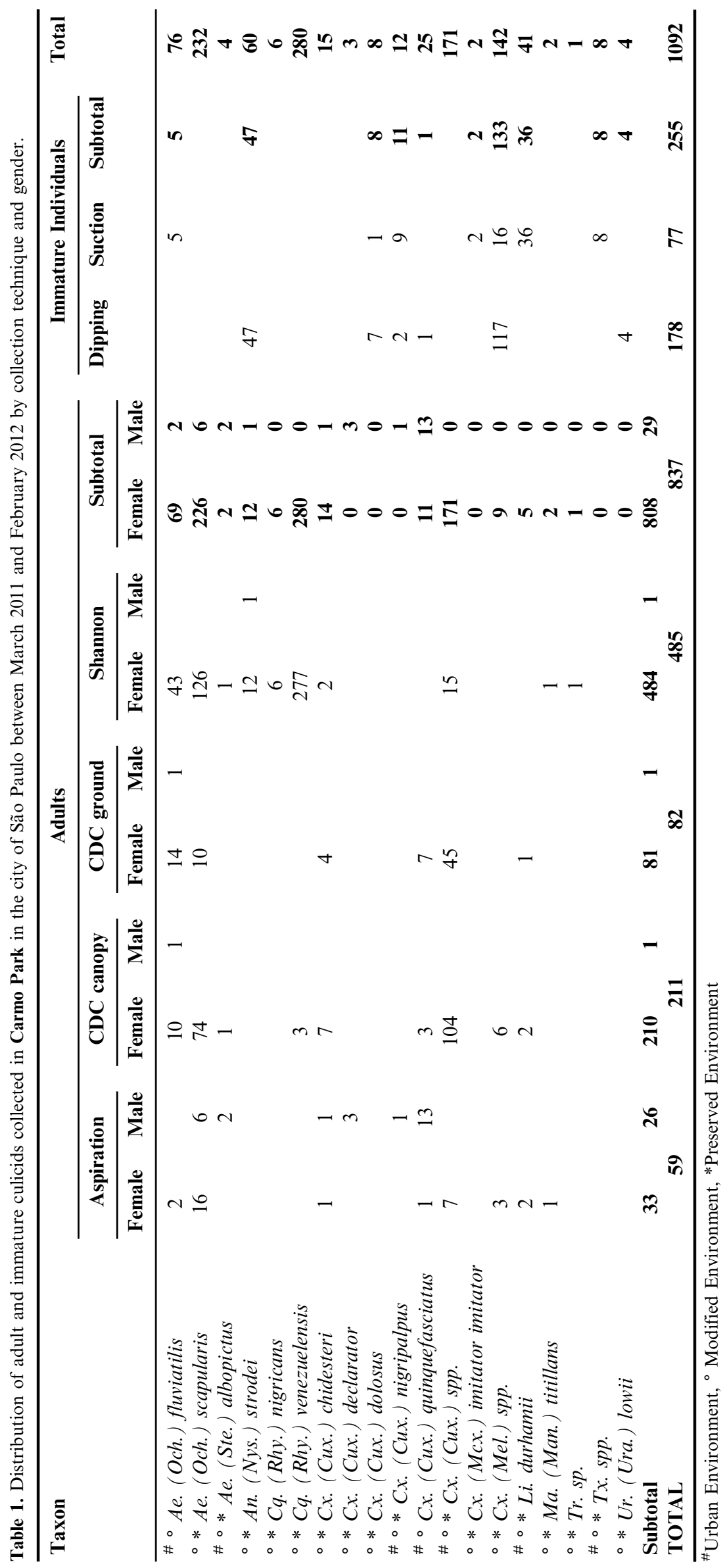


[808 (96.5\%) -,$+ 29(3.5 \%)$ - 0 ] ] and 255 immature individuals, giving a total of 1,092 mosquitoes distributed in nine genera (Aedes Meigen 1818, Anopheles Meigen 1818, Coquillettidia Dyar 1905, Culex Linnaeus 1758, Limatus Theobald 1901, Mansonia Blanchard 1901, Trichoprosopon Theobald 1901, Toxorhynchites Theobald 1901 and Uranotaenia Lynch Arribálzaga 1891) and nineteen taxonomic units.

Of the four techniques used, the Shannon trap was the most effective in terms of the number of adult mosquitoes collected, accounting for $58.0 \%$ (485) of the total, followed by the CDC light traps in the canopy with $25.2 \%$ (211); CDC light traps on the ground and the battery-powered aspirator, which accounted for $9.8 \%$ and $7.0 \%$ (82 and 59), respectively. Coquillettidia (Rhynchotaenia) venezuelensis (Theobald 1912), (33.4\%), Aedes (Ochlerotatus) scapularis (Rondani 1848) (27.7\%) and Culex (Culex) spp. Linnaeus $1758(20.4 \%)$ were the most abundant adult culicids (Table 1).

Collections of immature mosquitoes made using a dipper and a suction sampler resulted in 178 and 77 specimens $(69.8 \%$ and $30.2 \%$ ), respectively. Culex (Melanoconion) spp. Theobald 1903 (52.2\%) and Anopheles (Nyssorhynchus) strodei Root 1926 $(18.4 \%)$ were the most abundant taxonomic units (Table 1).

Collections in Chico Mendes Park yielded 4,416 adult

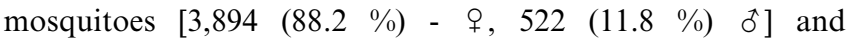
71 immature individuals, giving a total of 4,487 mosquitoes distributed in six genera (Aedes, Anopheles, Culex, Limatus, Mansonia and Trichoprosopon) and eighteen taxonomic units.

The CDC light traps in the canopy had the highest yield of adult mosquitoes and accounted for $42.0 \%$ of the total $(1,856$ specimens), followed by the Shannon traps, with $21.6 \%$ of the total ( 955 specimens), the aspirators, with $21.4 \%$ of the total (947 specimens), and the CDC light traps on the ground with $14.9 \%$ of the total (658 specimens). The taxonomic units Culex (Cux.) spp. (56.7\%) and Ae. (Och.) scapularis $(25.1 \%)$ were the most abundant adult culicids (Table 2).

When immature mosquitoes were collected using only the suction technique, Ae. (Ste.) albopictus (Skuse 1894) (73.2\%) was the predominant species, with 52 specimens collected (Table 2).

The sample-based species accumulation curves in both parks were close to the asymptote, and the total richness estimate was close to the observed richness, with a good degree of overlapping of confidence intervals (Figure 2).

\section{Discussion}

One of the aims of the inventory of Culicidae species in Carmo Park and Chico Mendes Park was to identify species that are important for public health; in other words, those that are potential vectors of pathogens or cause discomfort. The characterization of hematophagous mosquitoes found in parks located in urban environments produces data that can be used to support possible monitoring or control efforts by the public authorities responsible for these areas. According to Mascara et al. (2012), the use of a variety of traps and collection points in different locations and a search for breeding sites over a greater areas of the parks requires a greater collection effort but is necessary to ensure more representative sampling of the fauna. This strategy was adopted in the present study.

Although various studies have already been carried out in fragments of green areas inside urban São Paulo, the data accumulated from these studies are not comprehensive enough to allow us to claim that all the Culicidae fauna in these areas are known (Urbinatti et al. 2001, Taipe-Lagos \& Natal 2003, Montes 2005). Comparison of the findings of a preliminary study (Medeiros-Sousa et al. 2013) of Carmo Park and Chico Mendes Park with the data from the present study, which found nineteen taxons in Carmo Park, shows that eleven of these taxons had already been recorded and that eight were found here for the first time. The same comparison for Chico Mendes Park revealed that of the eighteen taxons identified, only six had also been found by Medeiros-Sousa et al. 2013. These results show that our study has helped provide a greater understanding of culicid fauna in these green areas. While the number of samplings was sufficient to obtain an inventory of culicids in the whole of Chico Mendes Park, based on the species accumulation curves the number of samplings for Carmo Park was considered satisfactory in the study area but inadequate for the park as a whole as its size made it unfeasible to explore areas farther from the defined collection points.

Culicids are of interest not only from an epidemiological perspective, an aspect that has been amply discussed, but also because some taxons can be used as bioindicators of environmental conditions in the areas they inhabit. The usefulness of mosquitoes as bioindicators is readily apparent if one assesses the extent of the changes that have occurred in a particular region and at the same time observes the increase or decrease in frequency of a particular taxon or whether the taxon has disappeared. Forattini et al. (1978) and Teodoro et al. (1994) defined Ae. scapularis as an abundant species in environments that have undergone change and a rare species in native forests. Ae. scapularis and mosquitoes in tribe Mansoniini are examples of culicids that are indicative of environments that have undergone major changes antropic, oscillating between presence or absence (Dorvillé 1995, Paula et al. 2012)

Although the parks studied here contain fragments of native forests, their location within built-up areas, the changes made to accommodate the parks and their users and the presence of humans in large numbers in and around them mean that these areas are under environmental stress. We found that Ae. scapularis is one of the most abundant species in the study area. The presence of Ae. scapularis in transformed environments may be related to the hematophagous habits of the females, which feed mainly on mammals, particularly humans and domestic animals (Forattini et al. 1986, 1989, Teodoro et al. 1994, Almiron \& Brewer 1996). It is well known that this species has a competitive advantage over other species in transformed environments as it lives in small temporary breeding sites in soil and its larval development cycle is considered fast compared with those of other culicids. Furthermore, its synanthropy and anthropophily are welldocumented characteristics. This species through experimental infection presented vectorial epidemiological capacity in transmit the virus Rocio in the Vale do Ribeira, Estado de São Paulo and of Dirofilaria immitis in coastal areas of the State of Rio de Janeiro, Brazil (Forattini 2002).

In Carmo Park the tribe Masoniini was represented by Cq. venezuelensis in high frequencies and Cq. nigricans (Coquillett 1904) and Ma. titillans (Walker 1848) but few in numbers while in the Chico Mendes park only this last species was found. In the immature stage, these culicids live in association with macrophytes that colonize lakes and act as indicators for the presence of these plants and in both parks was noted the presence of Typha domingensis Pers. (Typhaceae). 
Paula, M.B. et al.

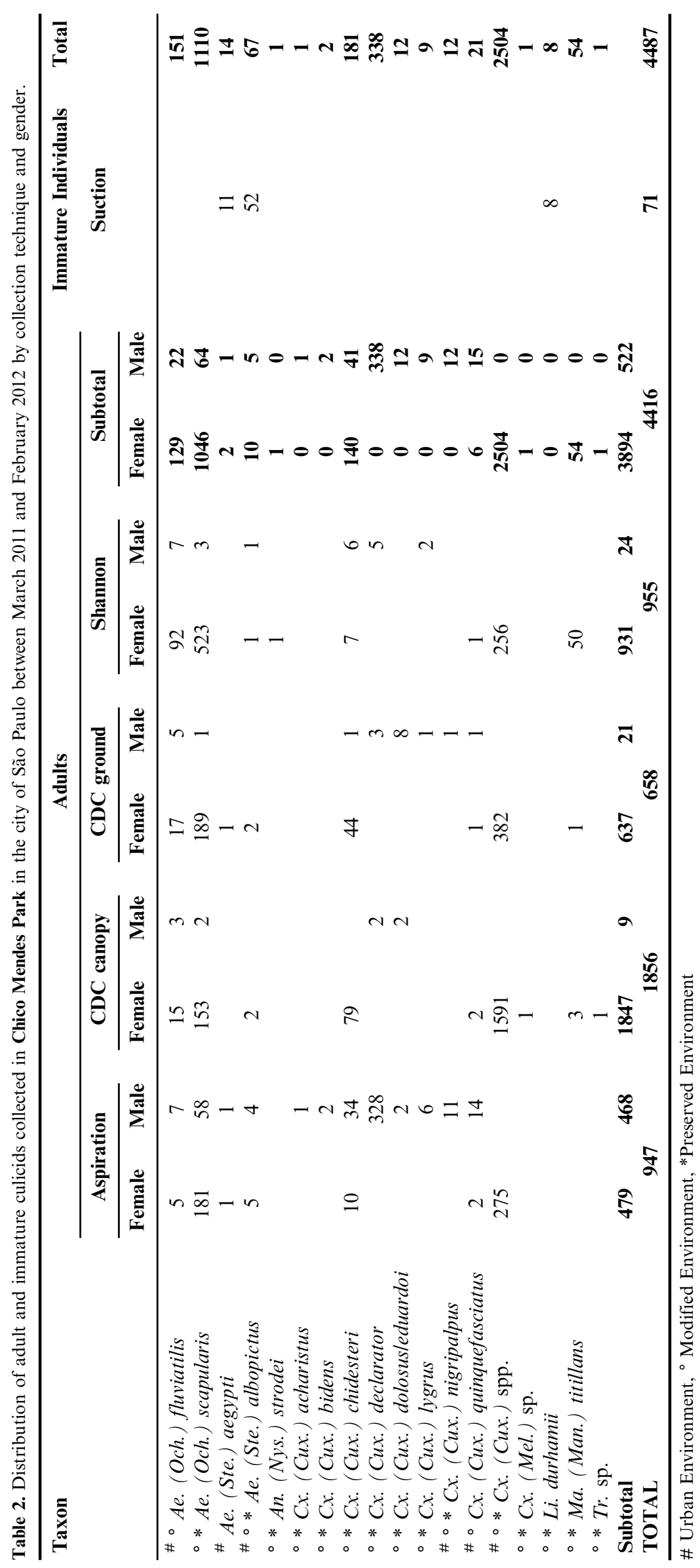




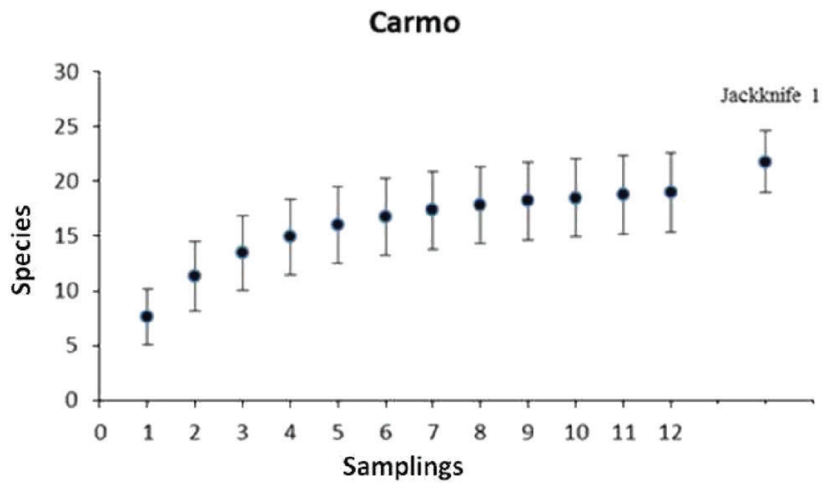

Chico Mendes

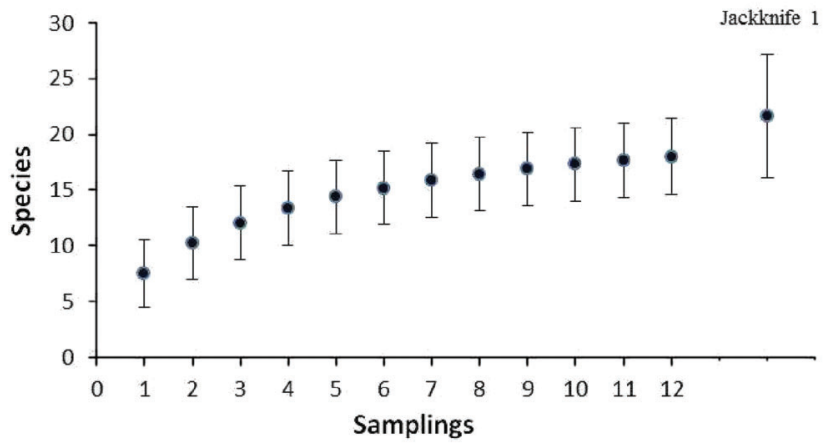

Figure 2. Sample-based species accumulation curves (jackknife 1) with a 95\% confidence interval for Carmo Park and Chico Mendes Park based on collections between March 2011 and February 2012.

Representatives of tribe Sabethini and Culex (Microculex) Theobald 1907 grow in treeholes, bromeliads and palm axils. They are frequently found in wild places and are considered indicators for such places. The fact that we found only a small number of sabethines (Limatus and Trichoprosopon and the absence of anophelines from subgenus Kerteszia Theobald 1905 may indicate marked anthropic environmental changes or environmental degradation in both parks, at least in the areas studied, making it difficult or impossible for these populations to survive there.

In Brazil, anophelines are generally common in rural or wild environments and rare in urban areas because their habitats require special environmental conditions (Forattini 2002). They are common on the outskirts of Manaus and other cities in the north of Brazil, and can cause outbreaks of malaria (Souza \& Castellón 2012). Our finding of An. strodei in both parks indicates that this species is not so selective in its choice of breeding sites, possibly tolerating polluted water, and that adults of this species may seek shelter in forest fragments in these

parks. Although it exhibits exophilic and zoophilic behavior, this species is considered a secondary or potential vector of human malaria (Consoli and Lourenço de Oliveira 1994). The relationship between anophelines and the presence of favorable man-made habitats can be considered to contribute to the maintenance of the population of these species in the parks (Gomes et al. 2008). However, because of their low frequency, the risk of these anophelines acting as vectors of Plasmodium spp. in the urban environment can be considered remote.

The taxon $C x$. (Cux.) spp. includes a range of species whose females are not morphologically distinct except for a few species.
Our finding of these mosquitoes in both parks and the fact that they were among the most abundant species suggest that these environments, which include preserved forest fragments and at the same time suffer the impact of humans, are suitable for this taxon. We found males of the following species in areas frequented by humans: Cx. (Cux.) acharistus Root 1927, Cx. (Cux.) bidens Dyar 1922, Cx. (Cux.) chidesteri Dyar 1921, Cx. (Cux.) declarator Dyar \& Knab 1906, Cx. (Cux.) dolosus Lynch Arribálzaga 1891/ Cx. (Cux.) eduardoi Casal \& Garcia 1968, Cx. (Cux.) lygrus Root 1927, Cx. (Cux.) nigripalpus Theobald 1901 and Cx. (Cux.) quinquefasciatus Say 1823. These mosquitoes are adapted to a wide range of different breeding grounds and shelters. Because of their eclectic feeding habits, they are considered potential vectors of arboviruses, which can cause infections in humans and domestic animals, and also a source of discomfort among people who frequent these parks and the surrounding areas (Urbinatti et al. 2001, Medeiros-Sousa et al. 2013). An epidemiologically important species is the common urban mosquito $C x$. quinquefasciatus, as it is known to be the main vector of filaria Wuchereria bancrofti and secondary vector of Oropouche virus in Brazil. It also has very anthropophilyc behavior and causes discomfort among residents of cities with untreated sewage. Another important mosquito found in the study is $C x$. (Cux.) nigripalpus a species with marked ornithophily and a known vector of St. Louis encephalitis virus (Forattini 2002).

Species in the genus Culex and subgenus Melanoconion can be found in natural or artificial environments and include eclectic species that can use humans and wild and domestic animals as sources of blood meals. They have the potential to become part of the natural cycle of some arboviruses, such as Venezuelan equine encephalitis virus (Forattini 2002, Montes 2005).

Exotic species such as Aedes (Ste.) aegypti (Linnaeus 1762) and Aedes (Ste.) albopictus, which were found in our study, are common in Brazilian cities and were expected to be found in both parks. In various situations these species can be found sharing the environment with a series of autochthonous mosquitoes from various genera, such as Anopheles, Coquillettidia, Culex, Mansonia, Limatus, Trichoprosopon, Toxorhynchites and Uranotaenia, as occurred here. In Brazil, Ae. aegypti, the vector of dengue and urban yellow fever, is highly adapted to the urban environment, where it reproduces in countless different types of artificial and natural receptacles. Ae. albopictus has the ability to spread rapidly, to occupy different environments and to take blood meals off various mammal species, leading to the hypothesis that it may be a potential vector of yellow fever and dengue in the Americas and potentially changing the epidemiology of the transmission of these diseases (Johnson et al. 2002).

In Brazil, the presence of various "autochthonous" species has been recorded on the outskirts and in more central areas of cities. Although exotic species have been considered important for public health, the importance of native fauna that has become established in densely inhabited areas should not be underestimated. Various such species have been found to have both the competence and capacity to transmit important pathogens and some have shown a progressive tendency to become domiciliated, increasing contact with humans and the risk of emerging infections by arboviruses (Dorville 1995, Smith et al. 2004, Guedes 2012). This adaptation is facilitated by the existence of environmental reserves in urban centers, such as the parks studied here. 
Attention should be paid to these areas as they are true green enclaves within cities and combine epidemiological conditions that favor the vector-borne transmission of disease (Lufchitz \& Marcondes 2011). It is important to include such areas in official entomological surveillance programs and to carry out regular investigations to determine whether arboviruses, particularly flaviviruses, may be circulating in these areas.

\section{Acknowledgments}

We would like to thank the State of São Paulo Research Foundation (BIOTA Program, Project 2010/51230-8) for providing financial support. We are also grateful to all the staff at the Department of Epidemiology in the Faculty of Public Health, University of São Paulo; the staff at the Office of Parks and Green Areas, Department of the Environment and Green Areas, São Paulo; and the staff at the Zoonosis Control Center, São Paulo City Hall, who helped collect and identify the specimens.

\section{References}

ALMIRÓN, W.R. \& BREWER, M.E. 1996. Classification of immature stage habitats of Culicidae (Diptera) collected in Córdoba, Argentina. Mem. Inst. Oswaldo Cruz. 91(1):1-9, http://dx.doi.org/ 10.1590/S0074-02761996000100001.

ANJOS, A.F. \& NAVARRO-SILVA, M.A. 2008. Culicidae (Insecta: Diptera) em área de Floresta Atlântica, no Estado do Paraná, Brasil. Acta Sci. Biol. Sci. 30(1):23-27, http://dx.doi.org/10.4025/ actascibiolsci.v30i1.1411.

BELKIN, J.N., SCHICK, R.X. \& HEINEMANN, S.J. 1966. Mosquito studies (Diptera: Culicidae). V. Mosquitoes originally described from Middle America. Cont. Am. Entomol. Inst. 1(6): 1-95.

BURNHAM, K.P. \& OVERTON, W.S. 1979. Robust estimation of population size when capture probabilities vary among animals. Ecology. 60(5): 927-936, http://dx.doi.org/10.2307/1936861.

COLWELL, R.K., MAO, C.X. \& CHANG, J. 2004. Interpolating, extrapolating, and comparing incidence-based species accumulation curves. Ecology. 85(10): 2717-2727, http://dx.doi.org/10.1890/03-0557.

CONSOLI, R.A.G.B. \& LOURENÇO-DE-OLIVEIRA, R. 1994. Principais mosquitos de importância sanitária do Brasil. Editora FIOCRUZ, Rio de Janeiro.

DORVILLÉ, L.F.M. 1995. Composição e aspectos da biologia da fauna de mosquitos (Diptera, Culicidae) da restinga de Barra de Maricá (RJ). Rev. Bras. Entomol. 39(1): 203-219.

EMPLASA. Empresa Paulista de Planejamento Metropolitano SA. 2011. Governo do Estado de São Paulo. Secretaria de Estado de Desenvolvimento Metropolitano. http://www.emplasa.sp.gov.br-atendimento@ emplasa.sp.gov.br. (accessed on January 18 ${ }^{\text {th }}$, 2014).

FORATTINI, O.P., GOMES, A.C., GALATI, E.A.B., RABELLO, E.X. \& IVERSON, L.B. 1978. Estudos ecológicos sobre mosquitos Culicidae no sistema Serra do Mar, Brasil. 1 - Observações no ambiente extradomiciliar. Rev. Saúde Pública. 12(4): 297-325.

FORATTINI, O.P, GOMES, A.C., NATAL, D. \& SANTOS, J.L.F. 1986. Observações sobre atividade de mosquitos Culicidae em matas primitivas da planície e perfis epidemiológicos de vários ambientes no Vale do Ribeira, São Paulo, Brasil. Rev. Saúde Pública. 20(3): 178-203.

FORATTINI, O.P., GOMES, A.C., NATAL, D.,KAKITANI, I. \& MARUCCI, D. 1989. Preferências alimentares e domiciliação de mosquitos Culicidae no Vale do Ribeira, São Paulo, Brasil, com especial referência a Aedes scapularis e a Culex (Melanoconion). Rev. Saúde Pública. 23(1): 9-19.

FORATTINI, O.P. 2002. Culicidologia Médica. EDUSP, São Paulo, v. 2, p. 860

GOMES, E.C.S., ALBUQUERQUE, C.M.R., SOUZA, J.R.B., ARRUDA, M.E. \& CONFALONIERI, U.E.C. 2008. Structure of Anopheles
(Diptera: Culicidae) population in areas with different degrees of human settlement: Cantá - Roraima - Brazil. Acta Amaz. 38(2): 321-329, http://dx.doi.org/10.1590/S0044-59672008000200016.

GUEDES, M.L.P. 2012. Culicidae (Diptera) no Brasil: Relações entre Diversidade, Distribuição e Enfermidades. Oecologia Australis. 16(2): 283-296, http://dx.doi.org/10.4257/oeco.

HARBACH, R.E. 2013. Mosquito taxonomic inventory. http://mosquito-taxonomic-inventory.info/. (accessed on January $18^{\text {th }}, 2014$ ).

IBGE. Instituto Brasileiro de Geografia e Estatística. 2010. IBGE Cidades@São Paulo. http://www.ibgegov.br/cidadesat/. (accessed on November 28th, 2013).

JOHNSON, B.W., CHAMBERS, T.V., CRABTREE, M.B., FILIPPIS, A.M., VILARINHOS, P.T., RESENDE, M.C., MACORIS, M.L. \& MILLER, B.R. 2002. Vector competence of Brazilian Aedes aegypti and Ae. albopictus for a Brazilian yellow fever virus isolate. Trans. R. Soc. Trop. Med. Hyg. 96(6): 611-613, http://dx.doi.org/ 10.1016/S0035-9203(02)90326-3.

LANE, J. 1953. Neotropical Culicidae. Ed.Universidade de São Paulo, São Paulo, v.2.

LUFCHITZ A.H.M. \& MARCONDES C.B. 2011. Culicidae. In Projeto Parques e Fauna: Plano de Manejo da Área de Proteção Ambiental Municipal da Ponta do Araçá - Diagnóstico de Fauna. Instituição Financiadora Prefeitura Municipal de Porto Belo. p. $48-53$.

MASCARA, D., COSTA FILHO, E.S., BATISTA, E. \& SILVA, S.P. 2012. Culicídeos da Serra do Itapeti. In Serra do Itapeti: Aspectos Históricos, Sociais e Naturalísticos (M.S.C. Morini \& V.F.O. Miranda, orgs). Canal 6 Editora, Bauru, p. 400.

MEDEIROS-SOUSA, A.R., CERETTI J.R., W., URBINATTI, P.R., CARVALHO, G.C., PAULA, M.B., FERNANDES, A., MATOS, J.R., M.O., ORICO, L.D., ARAUJO, A.B., NARDI, M.S., \& MARRELLI, M.T. 2013. Mosquito Fauna in Municipal Parks of São Paulo City, Brazil: A Preliminary Survey. J. Am. Mosq. Control Assoc. 29(3): 275-279, http://dx.doi.org/10.2987/12-6304R.1.

MONTES, J. 2005. Fauna de Culicidae da Serra da Cantareira, São Paulo, Brasil. Rev. Saúde Pública. 39(4): 578-584.

MORETI, C. \& FUNGARO, M.L. 2012. Guia dos parques municipais de São Paulo. 3 ed., Prefeitura de São Paulo, Secretaria do Verde e do Meio Ambiente. São Paulo. http://www.prefeitura.sp. gov.br/svmaparques.

NASCI, R.S. 1981. A lightweight battery-powered aspirator for collecting resting mosquitoes in the field. Mosq. News, 41(4): 808-811.

PAULA, M.B., GOMES, A.C., NATAL, D., DUARTE, A.M.R.C. \& MUCCI, L.F. 2012. Effects of Artificial Flooding for Hydroelectric Development on the Population of Mansonia humeralis (Diptera: Culicidae) in the Paraná River, São Paulo, Brazil. J. Trop. Med. ID 598789, 6 pages, http://dx.doi.org/10.1155/2012/ 598789.

REINERT, JF. 2001. Revised list of abbreviations for genera and subgenera of Culicidae (Diptera) and notes on generic and subgeneric changes. J. Am. Mosq. Control. Assoc. 17: 51-55.

SMITH, D.L., DUSHOFF, J \& MCKENZIE, F.E. 2004. The risk of a mosquito-borne infection in a heterogeneous environment. PLoS Biology. 2(11): 368, http://dx.doi.org/10.1371/journal.pbio. 0020368.

SOUZA, L.A.G. \& CASTELLÓN, E.G. 2012. Desvendando as fronteiras do conhecimento na região amazônica do Alto Rio Negro. http:// www.inpa.gov.br/arquivos/livro_fronteiras/02-Livro_Fronteiras.pdf. (último acesso em 27/01/2014).

STONE, A., KNIGHT, K.L. \& STARCKE, H. 1959. A synoptic catalog of the mosquitoes of the world (Diptera: Culicidae). Entomological Society of America, Maryland, v. 6, p.1-358.

TAIPE-LAGOS, C.B. \& NATAL, D. 2003. Abundância de culicídeos em área metropolitana preservada e suas implicações epidemiológicas. Rev. Saúde Pública 37(3): 275-279.

TEODORO, U., GUILHERME, A.L.F., LOZOVEI, A.L., SALVIA FILHO, V.L, SAMPAIO, A.A, SPINOSA, R.P, FERREIRA, 
M.E.M.C., BARBOSA, O.C. \& LIMA, E.M. 1994. Mosquitos de ambientes peri e extradomiciliares na região sul do Brasil. Rev. Saúde Pública. 28(2): 107-15.
URBINATTI, P.R., SENDACZ, S. \& NATAL, D. 2001. Imaturos de mosquitos (Diptera: Culicidae) em parque de área metropolitana aberto à visitação pública. Rev. Saúde Pública 35(5): 461-466.

\section{Erratum}

No artigo "Mosquito (Diptera: Culicidae) fauna in parks in greater São Paulo, Brazil” publicado do periódico Biota Neotropica, 15(3), na página 1 onde lia-se:

Marcia Bicudo de Paula ${ }^{I}$, Aristides Fernandes ${ }^{I}$, Antônio Ralph Medeiros-Sousa ${ }^{1}$, Walter Ceretti-Júnior ${ }^{I}$, Rafael Christe $^{I}$, Regina Claudia Stroebel $^{2}$, Leila Pedrosa ${ }^{2}$, Rosa Maria Marques de Sá Almeida ${ }^{1}$, Uellinton Damasceno Pereira ${ }^{3}$, Marcelo Cassiano de Oliveira Jacintho ${ }^{3}$, Delsio Natal', Mauro Toledo Marrelli ${ }^{14}$

Leia-se:

Marcia Bicudo de Paula ${ }^{I}$, Aristides Fernandes ${ }^{I}$, Antônio Ralph Medeiros-Sousa ${ }^{I}$, Walter Ceretti-Júnior ${ }^{I}$, Rafael Christe $^{I}$, Regina Claudia Stroebel $^{2}$, Leila Pedrosa ${ }^{2}$, Rosa Maria Marques de Sá Almeida ${ }^{1}$, Gabriela Cristina de Carvalho ${ }^{1}$, Uellinton Damasceno Pereira $^{3}$, Marcelo Cassiano de Oliveira Jacintho ${ }^{3}$, Delsio Natal ${ }^{1}$, Mauro Toledo Marrelli ${ }^{14}$ 